\section{$4 \quad$ Structure and culture in pre-industrial Cape Town: A survey of knowledge and ignorance ROBERT ROSS}

It is perhaps best to begin this analysis by examining the fount of power within the colony. In South Africa before 1870 , power was only very partially, though increasingly over time, a derivation of local relations of production and exchange. ${ }^{1}$ To the extent that power did depend on such relations, it was only at several removes, and, moreover, not on those located within the continent of Africa. Rather, power at the Cape derived in the first instance from the strength of the Dutch and British imperial systems, in which the colony at the southern tip of Africa was of minor and essentially strategic significance. This was of course by no means an atypical relationship between a colony and a colonising country.

The The concrete consequence of this rather abstract statement is the realisation the
prime locus of power in the colony and the city lay with the governor and his high officials, subject only to the constraints and orders that they received from Batavia, Amsterdam and London. Such power was manifest in their legal monopoly of force and thus of life, death and the could make reality ${ }^{2}$ This was the case not only during the period of Dutch East India hey could make realit Company rule, when the Council of Policy and the Court of Justice were composed of very much the same men (except that the governor did not sit on the latter since in criminal cases he had to confirm sentences). It continued to be the case after the arrival of the British, and even after the judicial reorganisation of 1827 . The judges, although now independent of the

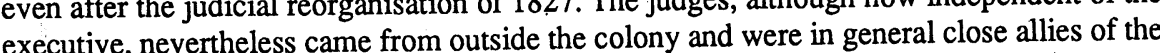
executive, nevertheless came from outside the colony and were in general close allies
high officials. ${ }^{3}$ And, of course, until 1854 , the governor and his council made the laws.

In the last instance, though, the power of the government did not rest on the law courts in in the several thousand imperial troops in or, in praster all, was only the colony were the theoretical guarantors of colonial cons. The army, after called out once to quell civil disorder, against the slaves' march on the city in Octobe 1808. ${ }^{4}$ Even at the height of the convict crisis the maintenance of order in Cape Town was left in the hands of the police (no more than 40 strong) although Lady Smith had to have an left in the Heerengracht, and soldiers protected the escort of dragoons when the maintained on a day-to-day basis by two less tangible, though no less real attributes, namely its symbolic power and the alliances that it could build up - in other words the practice of politics.

On the symbolic power of the successive governments, we know little. Such matters as 'state' ritual have yet to receive the serious attention of historians of the Cape, although such works as The Invention of Tradition edited by Eric Hobsbawm and Terence Ranger ${ }^{6}$ demonstrate the importance that should be attached not only to the inner practice but also to demonstrate the importan of the outer show had replaced the obvious ostentation of landed wealth by the less evident power of the bank balance. As a result, in the Netherlands civic and individual show had to perform the task left in England to broad acres. Certainly at the Cape symbolic displays of authority were regular and on a grand scale. The official diarist only became truly eloquent when describing the annual visits of the admiral of the return and outbound fleets, with a full description of the parades and the salutes fired. These were only exceeded by the grandiose pomp that accompanied the funerals of Cape governors and those of their wives. In these ceremonies, all men holding official office and the late governor's connections, many more than a hundred strong, followed the coffin in strict order of precedence.'

These great civic rituals were backed up by the regulation of the outward signs of status, so that the social hierarchy was continually visible. Clothing was rigorously regulated, with each grade in the social order having its own badges, from the wearing of embroidered silk reserved for the Council of Policy and their wives to the wearing of shoes, only allowed to the free. ${ }^{8}$ But the slaves did not escape the regulation of their lives, or at least their deaths. By an ordinance of 1754 the number of slaves allowed to follow a slave's funeral was dependent on the rank of the late man's owner.'

The British do not seem to have made use of such measures, unless the governor's ostrich-plumed uniform can be said to have replaced his predecessors' monopoly over the finest fabrics. Rather the British governors and high officials saw their position as that of the leaders of society. It is in this context that the letters of Lady Anne Barnard, for instance, should be read, as they demonstrate the process whereby the British attempted, successfully, to acquire social hegemony. The comments that Lady Anne and other observers make on the adoption by the colony's elite women of British fashions (replacing the French, which had been worn during the presence of a French garrison in the 1780s) should not be dismissed as mere tittle-tattle. ${ }^{10}$ Indeed they represent a clear political statement on behalf of the wearers, as definite, if somewhat less conscious, as the wearing of black, gold and green in South Africa today.

It is also in this context, and not just as some quirk of taste, that we should view the patronage by various British governors, notably Lord Charles Somerset and Sir Harry Smith (not coincidentally, the two most authoritarian), of the horse races at Green Point and the 'fox'-hunting (actually black-backed jackal) from Wynberg onto the Cape flats and in the Tijgerberg. ${ }^{11}$ They represented not just the barbarous recreations of the British military, but also one of the ways in which links were built up between the new rulers and the colony's elite, and helped transform the latter into overseas variants of the British landed gentry. ${ }^{12}$

Important though this outward show was, no government could survive entirely on the basis of funerals, fox-hunts, balls and gubernatorial receptions. To acquire the consent of sufficient proportion of the governed for it to function, it had also to demonstrate some material convergence with them. This, however, was not difficult. As has been pointed out for the general class of 'white settler' colonies, of which the Cape with its large slave (or ex-slave) and indigenous population was a somewhat aberrant example, 'political collaboration stemmed largely from economic dependence' ${ }^{13}$ Government demands were rarely considered exorbitant, and government patronage, direct or indirect, was very considerable. Moreover, the government was seen, correctly, as the main guarantor of the social order, with the result that those who profited from that order considered it importan not to undermine the basis of their own position. The compact was symbolised in the composition of the Legislative Council after 1827. The 'unofficial' members were to be chosen, so it was decreed from London and accepted in the Cape, from 'the Chief Landed proprietors and Principal merchants' of the colony. ${ }^{14}$

This compact only broke down on three occasions, during the Patriot movement of the $1780 \mathrm{~s}$, the resistance to the slave ordinances of the late $1820 \mathrm{~s}$ and early $1830 \mathrm{~s}$, and the convict crisis and its aftermath from 1848 to 1854 . Even then, the crises were only 
temporary. As for the first two, it was clear that the government had not maintained its side of the compact (although it could be argued that before the 1780s the burghers were too weak and the VOC too strong for there to have been a tacit compact at all). On the former occasion, the officials of the VOC had engrossed too much of the economic activity of the

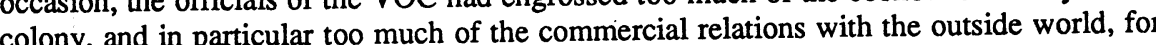
colony, and in particular ${ }^{15}$ In this sense it was a replay of the W. van der Stel affai earlier in the century. On the second occasion, the government had been forced by its own superiors in London to abrogate its role as the maintainer of social order and was required, against its will, to make half-hearted attempts to benefit the underlings. ${ }^{16}$

The third occasion, that of the convict crisis, is more complex. Essentially, though, three strands can be disentangled. In the first place, there was a strong feeling within the colony that the time had come for the development of various forms of representative institutions. In some ways, this was a move which went against the immediate financial interests of the colony, since it would eventually entail the withdrawal of British support for the British troos troops stationed in South Africa, whose prence al Against this, there was the belief that the colony had now achieved sufficient 'maturity' to make it worthy of a parliament, and that this maturity in itself would ensure economic survival. In this, the example of other British colonies, notably Canada and Australia, was crucial.

Secondly, there was by the late 1840 s considerable opposition to what has been termed the 'family compact' whereby the Colonial Secretary, John Montagu, controlled the the 'family compact' whereby the Colonial Secretary, John Montagu, controlled the friends and family rather than to extend the political support for the administration. Thirdly, there was the symbolic importance of the convict question. The colony's elite (it is certainly too early to describe them as a ruling class, since their control over the government was still very limited) believed, with justice, that their control over the mass of government was still very limited) believed, with justice, that their control over the mass of the Cape's population was weak, and interpreted all resistance to itself as 'crime'. It was therefore in general resolutely opposed to the introduction of yet more "criminals", especially as these were Europeans whose presence would offend against the racial
hierarchy which was being re-established as a means of discipline in the aftermath of emancipation.

Although the first and, above all, the third, of these conflicts were played out in the political theatre of Cape Town, and although the Cape Town municipality took a leading polical in the colony, nevertheless, politics were not primarily about specifically Capetonian issues. Within the Cape Town municipality itself, there were of course disputes on the normal range of administrative matters but, so far as I am aware, they had not yet developed into an articulation of specific interests within the town, although perhaps the problems round the harbour and in the compex of slum formation and sanitation may already have been harbour and in the social oppositions within the town were expressed beginning to take this form. ${ }^{18}$ Rather, the social oppositions within the town were expressed judiciary, a pattern that is not unfamiliar in South Africa's more recent history. The economy of Cape Town was thus dominated by its dual function as a port and a - government centre. Basically, therefore, it was a service city. This had considerable consequences for the size of the economic enterprises. There were only a few with large workforces. The largest establishment would have been the docks, and the largest public works the construction of the breakwaters, which both in the in the mid-nine materials was also on a large scale, whether in the Robben Island quarring (lime. ${ }^{19}$ There were also some building contractors who worked, at least for the erection of particular buildings, on a fairly large scale.$^{20}$ Apart from these, the biggest employers were those concerned with the preparation of foodstuffs, above all the slaughterhouses, the corn mills and the breweries, but even these were, with some exceptions, rather small. ${ }^{21}$

Manufacturing industry, in contrast, was virtually absent. In this sector, Cape Town's requirements were largely met by enterprises which had an artisanal character, with small tailors' shops, smithies, carpenters' works and so forth. Fishing was also organised on a small scale, with many individual boat owners, who were often free blacks.

The retailing of food was also a very important source of income. Initially this was very largely in the hands of the slaves, who had to render 'coeli-geld' to their masters at the end of the day or week - or in other words rent for their own time. This was a practice which could lead to considerable conflict, as slaves who had failed to accumulate sufficient money at the end of the day were liable to punishment. The threat of such punishment was indeed one of the major motives for slaves to run away. ${ }^{22}$ On the other hand, those few who were successful were sometimes able to buy their own freedom with the profits from their trading. By the early nineteenth century this meant that there was a substantial minority of free blacks (in other words manumitted slaves) among the food retailers. ${ }^{23}$ Indeed, in 1812 , all Cape Town's 'chop houses', or cheap restaurants, which catered largely for sailors and the urban poor, were in the hands of free blacks. ${ }^{24}$

Certainly in these artisanal, small trading and fishing occupations, there was never a clear racial division of labour in Cape Town. From the time of slavery, many of the skilled trades were performed by both slaves and free, and by both free blacks and whites; and since often the tasks were for one man, with no division of labour in the production process, there was also no clear racial hierarchy within the trade. Skilled slaves could also achieve a considerable degree of independence. To take one example, Louis of Mauritius, a tailor, was hired out by his owner to his wife, a free woman, and was thus presumably able to live a life free from the worst trammels of slavery, at least until the impending death of his wife threatened to end his privileged status and drove him to lead the slave 'rebellion' of $1808 .^{25}$ There will have been few slaves who had Louis's degree of independence, but nevertheless the number in Cape Town who were potentially at least able to exploit the advantages of their degree of skill would not have been negligible.

It would be fascinating to have an occupational census of Cape Town, cross-tabulated by status or race, but although the documentary record would probably allow this, at least for around $1820,{ }^{26}$ it has yet to be done. Nevertheless, speculating on the results of such a census, it seems reasonable to assume that both during slavery and thereafter there would have been a large number of occupations which were in no way the monopoly of either slaves (or ex-slaves) or the free, so that there was a peculiarly convoluted - and in the South African context, specifically Capetonian - interplay between racial categorisation and occupation. Yet, it would be the worst kind of economism to assume that this entailed either equality or open social interaction between individuals of differing legal or, later, so-called 'racial' status. Rather, there was an elaborate etiquette regulating their relationships. (This point would be made stronger if I was writing in Dutch, or for that matter in French or in Afrikaans, where the word 'etiquette' has maintained its original meaning of 'label' in addition to that current in English.) In Cape Town, more than elsewhere in South Africa, social relations have never been a direct function of economic activity, but have been heavily influenced by all sorts of other considerations, including physiognomy, clothing, language, religious affiliation, even food, which are at best tangentially or derivatively linked to the production and exchange processes of the town. ${ }^{27}$

If these arguments have any validity, then they signal and justify theoretically the importance of a field of study in which, as yet, our ignorance is great, though not total. This is the question of the various cultures to be found in the city. In the recent historiography of 
South Africa, the study of cultures has primarily been concerned with two problems, namely their use for the establishment of hegemony, in the Gramscian sense, and with the opportunities they gave for the maintenance of African resistance. ${ }^{28}$ In Cape Town, it had opportunite establishment and marking of 'identity', a term which is of great importance for the modern sociology of the city. ${ }^{29}$ This is one of the contexts in which we must see the Green Point horse races and the fox-hunting meets, but it is also, perhaps more interestingly, an important facet of the relevance of the Islamic rites and conversions described by Rober Shell ${ }^{30}$ Shell has shown how Islam developed the institutions which it had evolved during the period of slavery to provide a haven for many disadvantaged men and women of all nationalities. Although Islam was primarily a religion of the somewhat better situated among the disadvantaged, it could also act as a bridge between the artisans and the smal independent traders, on one hand, and some of the manual labourers, on the other.

Valuable though this study and others which deal with Islam are, ${ }^{31}$ they present a potential distortion for the study of Cape Town as a whole if used in a way their authors would not intend. The greater historical visibility - and also to a certain extent the exoticism - of the Muslim community has tended to divert attention from the various other cultural manifestations in the city. Islam, after all, was in some ways a religion and a way of life that set its adherents apart from the other inhabitants of the city, except to the extent that they could be converted. What we need to know more about are the ways in which people who were initially outside the established order came to make a cultural claim for a place within it. This would require, above all, placing the history of the Christian churches and of education definitely in their social context, since it was by converting to Christianity and by acquiring education that such a claim could be made. 'Respectability', too, had its origins in the nineteenth century, but as yet we do not have much idea of the contours of its development.

There were, thus, two major strategies among the upper levels of the so-called 'coloured' population. Either they rejected the cultural hegemony of the whites to take up Islam or they populat the terms of the 'white' society, taking on Christianity and Western education. Only from the last years of the nineteenth and the early twentieth centuries, with the development of the Stone meeting and later of the APO, was there any attempt to challenge the established order on its own terms. ${ }^{32}$ However, in particular the strategy of respectability for individuals is in itself evidence that things had changed since the time of the VOC, when full acceptance of the very small number of upwardly mobile, particularly among the women, was not impossible. ${ }^{33}$ There were two reasons for this. First, with the economic expansion of Cape Town and above all with the emancipation of slaves, there were many more potential recruits to upper- and middle-class society, so that a pattern, if not a community, could develop. Previously such social careers had been largely a matter of individual choice and fortune. Secondly, increased racism among the whites meant that the individual choice and fortune. Secondly, increased racism among the whites meant that the
great majority of men and women of slave descent were seen by the elite as 'coloureds', and thus not as potential peers. 'Respectability' thus became a terminus, not a way-station.

Even if these suppositions are accurate, there remain considerable problems. Most fundamentally, the ways in which social status was marked and social hierarchies were maintained were not as clear as might be suggested. In Cape Town, more than anywhere else in South Africa, it is not enough merely to look at economics in order to gauge status, but neither should one fall into the opposite trap of accepting at face value the racis classification schemes of the elite. There were very important social boundaries, but exactly where they were and how they were maintained are far from clear. The colour line was wefinitely blurred, but it was nonetheless clearly present. Indeed some of the institutions by which it might seem to have been broken, such as the 'Rainbow balls' (organised opportunities for British officers and others to pick up 'coloured' women), probably did more to confirm both those whites who frequented such gatherings and those who condemned them in their stereotypical views of 'coloured' behaviour. ${ }^{34}$

These ambiguities can be seen clearly in the residential pattern that emerged after emancipation. The ex-slaves took advantage of the opportunities they now had to desert their masters en masse. By the 1850 s, living-in servants were virtually unobtainable, since this carried too much of the stigma of slavery. ${ }^{35}$ Indeed in only one house in Cape Town have the outhouses which were the old slave quarters survived. ${ }^{36}$ The consequence, of course, was the establishment of Cape Town's slums, in which the ex-slaves exchanged the exploitation of their masters for that of their new landlords, who were very often the same people, as slave compensation money was often invested in house-building. ${ }^{37}$ In these slums individuals of all origins were to be found ${ }^{38}$ but it is most questionable whether those Europeans who had been forced by poverty to take up residence in the alleys along the foreshore were ever able to quit them, or to move to the delights of, say, the Gardens. They were thus likely to be assimilated into Cape Town's lumpenproletariat, which itself was then categorised as 'coloured'.

It was from among the slaves and those ex-slaves who had not made a bid for respectability, that the liveliest expressions of Capetonian popular culture emanated. At the beginning of the nineteenth century Lichtenstein noted that every slave group had its own musical style ${ }^{39}$ and in the $1820 \mathrm{~s} \mathrm{W.} \mathrm{W.} \mathrm{Bird} \mathrm{observed:}$

The grand display is in the outskirts of the town, to which the black population rush, on a Sunday, and go through their various awkward movements in quick or slow time, according to the taste of the dancers. The Sunday dance is accompanied by native music of every description. The slave boys from Madagascar and Mosambique bring the stringed instruments of their respective tribes and nation, from which they force sounds, which they regard as melodious. The love of dancing is a ruling passion throughout the Cape population in every rank; but music, The love of dancing is by a small part of the society, is here a passion with the negro alone. ${ }^{40}$

It stands to reason that the tradition embodied in such events would not have been extinguished by emancipation, although no doubt it was substantially altered. Perhaps the 'Coon carnival' as it was organised from the 1890 s on, was in some ways a transformation of it. However, as yet we know little or nothing about such manifestations. This is greatly to be deplored, not merely because of the intrinsic interest of such events (which can easily lead unwary researchers into the arid antiquarianism of folklore studies) but also because they almost certainly would provide an entry into the visions of their society held by those whose place in it was modest and oppressed. This supposition, moreover, is strengthened by the accounts we do have of slave celebrations of emancipation, which describe parades through the streets of Cape Town with banners flying. (Later they became merely public holidays. $)^{41}$ What we can be sure of is that the city's elite looked disparagingly on such events. In common with bourgeois Victorians throughout the world, they saw manifestations of certain popular culture as lewd indiscipline and a potential challenge to the established hierarchy. In this they were united. ${ }^{42}$

This is another illustration of the fact that in Cape Town allegiances were generally situational rather than immutable. Tony Kirk made a distinction between 'the mercantile elite' and 'the rising commercial class', in mid-nineteenth-century Cape Town. ${ }^{43} \mathrm{His}$ argument is that the two groups can be distinguished on the basis of their economic activities, with the former essentially dependent on their relations with large British shipping and mercantile houses, in which they were often partners, while the latter's financial resources were locally derived and in general re-invested rather than realised for an eventual retirement in Europe. It was in other words a distinction between the financiers and the traders. This distinction, it is claimed, was reflected in the political positions of the two groups during the mid-century crisis. The mercantile elite were in general more conservative and more likely to support the colonial government, while the traders were 
